\title{
Bank Credit, Public Financial Incentives, Tax Financial Incentives and Export Performance During the Global Financial Crisis: A Review
}

Volume: 8

Issue: 2

Month: March

Year: 2020

P-ISSN: 2319-961X

E-ISSN: 2582-0192

Received: 11.01.2020

Accepted: 14.02.2020

Published: 01.03.2020

Citation:

Luke Emeka Okafor. "Bank Credit, Public Financial Incentives, Tax Financial Incentives and Export Performance During the Global Financial Crisis: A Review." Shanlax International Journal of Economics, vol. 8, no. 2, 2020. pp. 1-4.

DOI: https://doi.org/10.34293/ economics.v8i2.2090

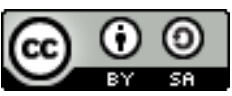

This work is licensed under a Creative Commons Attribution-ShareAlike 4.0 International License

\section{Luke Emeka Okafor}

School of Economics, University of Nottingham Malaysia, Semenyih, Selangor, Malaysia

\section{Abstract}

The EU-EFIGE/Bruegel-Unicredit comparable dataset consisting of firms operating in Austria, France, Germany, Italy, Hungary, Spain, and the UK was used for the empirical analysis. To cover the gaps in the existing literature, the study under review investigates the effects of access to credit and financial incentives on firms' export performance during the period of the 2008 global financial crisis. This includes examining the moderating roles of firm size and financial development on the link between access to credit or financial incentives and export performance.

Keywords: Credit, Public Financial Incentives, Tax Incentives, Export performance, Financial Development

This paper reviews Okafor L. E, Bhattacharya, M and Apergis, N's (2020) evidence that access to bank credit, public financial incentives, and tax incentives during the 2008 Global Financial Crisis (GFC) led to improved export performance.Before this study, the strand of literature that relates to finance and export performance used different proxies for credit to capture financial constraints (Muûls, 2015; Wagner, 2012, 2014). As a result, the issue of whether access to financial incentives, such as public financial incentives or financial tax incentives helps to promote export performance was unexplored. Furthermore, the issue of whether financial development improves export performance or whether the effects of access to credit and financial incentives differ by firm size was not explored. In the context of the study under review, the degree of access to external capital is used as a proxy variable to capture financial development(Okafor et al., 2020).

The EU-EFIGE/Bruegel-Unicredit comparable dataset consisting of firms operating in Austria, France, Germany, Italy, Hungary, Spain, and the UK was used for the empirical analysis (Altomonte \& Aquilante, 2012; Altomonte, Aquilante, \& Ottaviano, 2012).

Okafor L. E, Bhattacharya, M and Apergis, N's (2020) study made important contributions to the strand of literature dealing with the interplay between finance and export performance. First, unlike previous studies that used credit as a proxy for financial constraint, the study under review used both public financial incentives and tax financial incentives in addition to credit to ascertain the effects of credit market frictions on export performance during a crisis period. Second, the study demonstrates that the influence of access to credit or public financial incentives varies with the level of financial development during the crisis period. Third, the study shows that the effects of public financial incentives or financial tax incentives on export performance differ by firm size. 
In general, the findings of the study show that firms that obtained credit or benefited from public financial incentives or financial tax incentives in the previous period exhibited better export performance during the 2008 global financial crisis compared to those firms that did not. Access to a credit or financial incentives has a significant positive impact on export performance as measured by either export intensity or the number of product lines exported to a firm's top three destination countries during the crisis period.

The endogenous treatment effects (ETE) estimator was used in the study to address potential endogenous issues. Endogeneity bias may arise from omitted variables. For instance, financial institutions have access to more information about firms and thus know more about the efficiency of firms compared to researchers working with a limited set of information for each firm (Contessi \& De Nicola, 2012). Also, treatment status, such as a financial incentive indicator, is not random. This is because older, larger, and more experienced firms are more likely to apply for bank loans or financial incentives given their better resources, networks and competences compared to younger, smaller and less experienced firms (Bannò \& Sgobbi, 2010; Duguet, 2004; Okafor et al., 2020). The ETE estimator makes it possible for one to estimate the causal effect of receiving treatment, such as obtaining credit or benefiting from financial incentives, on treatment outcome, such as export performance, using observational data(Okafor et al., 2020; StataCorp, 2017; Wooldridge, 2009). The use of the ETE estimator allowed the researchers to obtain reliable estimates of access to credit or financial incentives on export performance during the crisis period.

The findings of the study have important policy implications, especially during a financial crisis period. Policies that improve firms' access to credit and financial incentives during the periods of credit frictions, such as the 2008 GFC, can help to promote export competitiveness. In general, export competitive countries during a financial crisis are better placed to minimize negative shocks to employment, output, and economic growth compared to those that are not. Furthermore, the findings from the study suggest that financial development is important for enhancing export competitiveness. Policies that promote financial sector development can help to enhance export performance during the period of a financial crisis (Okafor et al., 2020).

The findings of the study under review call for further investigation of the role of finance in stimulating international competitiveness. For instance, studies from the strand of literature that deals with firm behavior and international trade suggests that the use of imported inputs or imported capital improves firm productivity, especially for firms that have the requisite level of absorptive capacity (Kasahara \& Rodrigue, 2008; Okafor, Bhattacharya, \& Bloch, 2017; Yasar, 2013). The use of imported inputs or capital in the production process allows firms to improve productivity through learning from knowledge embodied in foreign inputs, foreign capital, or imitating foreign technologies. This suggests that trade in intermediate inputs and capital is a source of international technology transfer (Acharya \& Keller, 2009; Okafor, 2014, 2020; Okafor et al., 2017; Okafor \& Teo, 2019). Given the importance of trade in intermediate inputs in promoting international technology transfer, it would be interesting to find out if firms that had access to credit and financial incentives during the crisis period utilized more imported inputs, imported capital or imported services in the production process compared to those firms that did not.

Tourism is an important industry in several countries. This is because, it contributes to employment generation, income creation for many individuals, a source of foreign exchange earnings, and help to promote economic growth (Khalid, Okafor, \& Aziz, 2019; Khalid, Okafor, \& Shafiullah, 2019; Okafor, Khalid, \& Then, 2018; Shafiullah, Okafor, \& Khalid, 2019). The tourism industry, however, is highly vulnerable to negative shocks resulting from the financial crisis. Therefore, future studies could explore whether tourism businesses that obtained credit or benefited from financial incentives provided by the public sector during the 2008 global financial crisis exhibited better export performance compared to those that did not.

In conclusion, access to loanable funds for investment during the period of crisis is important for an economy to withstand the negative effect of 
the economic downturn (Campello, Graham, \& Harvey, 2010; Okafor \& Tyrowicz, 2009, 2010). It would be interesting for future studies to investigate whether firms that obtained credit or benefited from financial incentives during the crisis period exhibited different investment behavior compared to those that did not.

\section{References}

Acharya, R.C. and Keller, W. "Technology Transfer through Imports." Canadian Journal of Economics, vol. 42, no. 4, 2009, pp. 1411-1448.

Altomonte, C., Aquilante, T. and Ottaviano, G.I. The Triggers of Competitiveness: the EFIGE Cross-Country Report, Bruegel Blueprint Series, 2012.

Altomonte, C. and Aquilante, T. "The EU-EFIGE Bruegel-Unicredit Dataset." Bruegel Working Paper, 2012.

Bannò, M. and Sgobbi, F. "Firm Participation in Financial Incentive Programs: The Case of Subsidies for Outward Internationalisation." Journal of Policy Modeling, vol. 32, no. 6, 2010, pp. 792-803.

Campello, M., Graham, J.R. and Harvey, C.R. "The Real Effects of Financial Constraints: Evidence from a Financial Crisis." Journal of Financial Economics, vol. 97, no. 3, 2010, pp. 470-487.

Contessi, S. and De Nicola, F. "What do we know about the Relationship between access to Finance and International Trade?." Federal Reserve Bank of St. Louis Working Paper Series 2012-054, 2012.

Duguet, E. "Are R \& D Subsidies a Substitute or a Complement to Privately Funded R \& D?." Revue d'Economie Politique, vol. 114, no. 2, 2004, pp. 245-274.

Kasahara, H. and Rodrigue, J. "Does the Use of Imported Intermediates Increase Productivity? Plant-Level Evidence." Journal of Development Economics, vol. 87, no. 1, 2008, pp. 106-118.

Khalid, U., and Aziz, N. "Armed Conflict, Military Expenditure, and International tourism." Tourism Economics, 2019.
Khalid, U., Okafor, L.E. and Shafiullah, M. "The Effects of Economic and Financial Crises on International Tourist Flows A Cross-Country Analysis." Journal of Travel Research, vol. 59, no. 2, 2019.

Muûls, M. "Exporters, Importers, and Credit Constraints." Journal of International Economics, vol. 95, no. 2, 2015, pp. 333-343.

Okafor, L.E., Bhattacharya, M. and Apergis, N. "Bank Credit, Public Financial Incentives, Tax Financial Incentives and Export Performance During the Global Financial Crisis." The World Economy, vol. 43, no. 1, 2020, pp. 114-145.

Okafor, L.E., Bhattacharya, M. and Bloch, H. "Imported Intermediates, Absorptive Capacity and Productivity: Evidence from Ghanaian Manufacturing Firms." The World Economy, vol. 40, no. 2, 2017, pp. 369-392.

Okafor, L.E. and Teo, W.L. "2018 WTO Trade Policy Review of Malaysia." The World Economy, vol. 42, no. 12, 2019, pp. 3447-3463.

Okafor, L.E. and Tyrowicz, J. "Foreign Debt and Domestic Savings in Developing Countries." Latin American Business Review, vol. 9, no. 3-4, 2009, pp. 189-226.

Okafor, L.E. and Tyrowicz, J. "Saving Less When There is More Foreign Lending? Foreign Debt and Savings in Developing Countries." Journal of Economic Policy Reform, vol. 13, no. 3, 2010, pp. 213-223.

Okafor, L.E. Essays on International Activities of Firms, Innovation, and Financial Constraints, Monash University, 2014.

Okafor, L.E. Khalid, U. and Then, T. "Common Unofficial Language, Development and International Tourism." Tourism Management, vol. 67, 2018, pp. 127-138.

Okafor, L.E. “Export Market Destinations, Imported Intermediates, and Productivity: Firm-level Evidence from Ghana." The International Trade Journal, 2020, pp. 1-28, https://doi.or g/10.1080/08853908.2020.1718567.

Shafiullah, M., Okafor, L.E. and Khalid, U. "Determinants of International Tourism Demand: Evidence from Australian States 
and Territories." Tourism Economics, vol. 25, no. 2, 2019, pp. 274-296.

Stata Statistical Software: Release 15, StataCorp LLC, 2017.

Wagner, J. "Credit Constraints and Exports: A Survey of Empirical Studies using Firm-Level Data." Industrial and Corporate Change, vol. 23, no. 6, 2014, pp. 1477-1492.

Wagner, J. "Credit Constraints and Exports: Evidence for German Manufacturing Enterprises." CESIS Electronic Working Paper Series
No. 286, 2012, http://EconPapers.repec.org/ RePEc:lue:wpaper:251

Wooldridge, J.M. "On Estimating Firm-Level Production Functions Using Proxy Variables to Control for Unobservables." Economics Letters, vol. 104, no. 3, 2009, pp. 112-114.

Yasar, M. "Imported Capital Input, Absorptive Capacity, and Firm Performance: Evidence from Firm-Level Data." Economic Inquiry, vol. 51, no. 1, 2013, pp. 88-100.

\section{Author Details}

Luke Emeka Okafor, School of Economics, University of Nottingham Malaysia, Semenyih, Selangor, Malaysia

Email ID:Luke.Okafor@nottingham.edu.my. 